
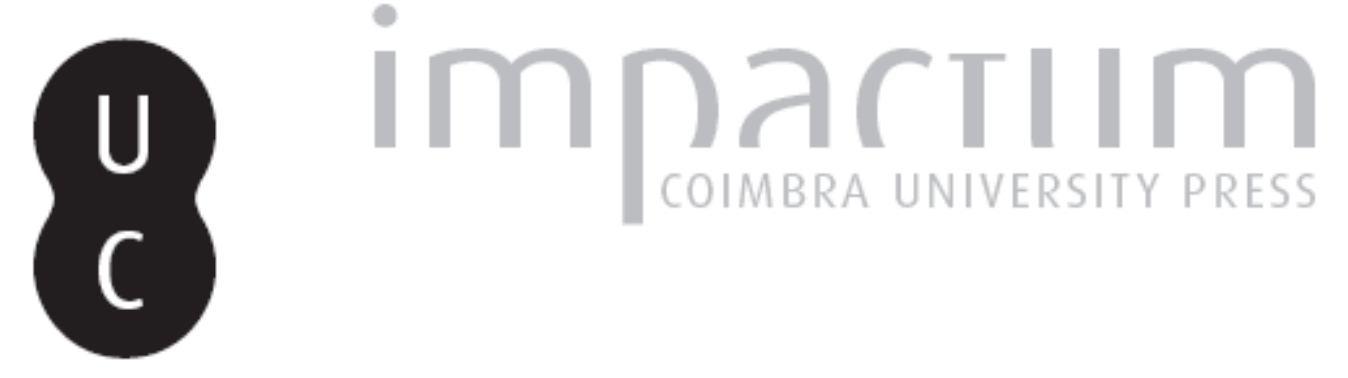

\title{
O pensamento inaugural dos direitos humanos pelas lições dos sofistas
}

\section{Autor(es): Bentes, Hilda Helena Soares}

Publicado por: Universidade Católica de Petrópolis

URL persistente:

URl:http://hdl.handle.net/10316.2/33886

DOI:

DOI:http://dx.doi.org/10.14195/2175-0947_1-2_7

Accessed : $\quad$ 26-Apr-2023 14:27:50

A navegação consulta e descarregamento dos títulos inseridos nas Bibliotecas Digitais UC Digitalis, UC Pombalina e UC Impactum, pressupõem a aceitação plena e sem reservas dos Termos e Condições de Uso destas Bibliotecas Digitais, disponíveis em https://digitalis.uc.pt/pt-pt/termos.

Conforme exposto nos referidos Termos e Condições de Uso, o descarregamento de títulos de acesso restrito requer uma licença válida de autorização devendo o utilizador aceder ao(s) documento(s) a partir de um endereço de IP da instituição detentora da supramencionada licença.

Ao utilizador é apenas permitido o descarregamento para uso pessoal, pelo que o emprego do(s) título(s) descarregado(s) para outro fim, designadamente comercial, carece de autorização do respetivo autor ou editor da obra.

Na medida em que todas as obras da UC Digitalis se encontram protegidas pelo Código do Direito de Autor e Direitos Conexos e demais legislação aplicável, toda a cópia, parcial ou total, deste documento, nos casos em que é legalmente admitida, deverá conter ou fazer-se acompanhar por este aviso.

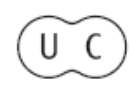



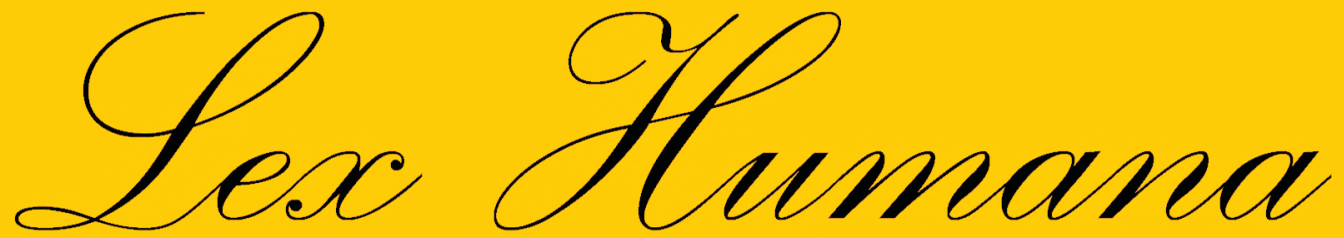

Revista do Programa de Pós-Graduação em Direito da UCP

ISSN(e) 2175-0947

Universidade Católica de Petrópolis Rua Benjamin Constant, 213 - Petrópolis - Centro CEP 25610-130

Tel: (24) 2244-4000 E-mail: lexhumana@ucp.br 


\title{
O Pensamento Inaugural dos
}

\section{Direitos Humanos Pelas LiçÕes dos Sofistas}

\author{
Hilda Helena Soares Bentes ${ }^{1}$
}

Resumo: Propõe-se a analisar as primeiras manifestações de um pensamento igualitário, base dos direitos do homem na filosofia jurídica moderna, através do debate travado entre as concepções de phýsis e nómos, iniciado pelos pré-socráticos e desenvolvido intensamente pelos sofistas.

Palavras-Chave: Filosofia Antiga. Phýsis x Nómos. Filosofia do Direito.

Abstract: It seeks to analyze the emergence of an egalitarian thinking, basis of the human rights studied in modern Philosophy of Law, mainly through the debate initiated by the presocratics and deeply developed by the sophists upon the conceptions of phýsis and nómos.

Keywords: Ancient Philosophy. Phýsis x Nómos. Philosophy of Law.

\section{INTRODUÇÃO}

Pretende-se fazer uma investigação no pensamento dos présocráticos e dos sofistas, particularmente direcionada para a discussão travada em torno da antítese phýsis x nómos, com vistas a detectar o embrião da ideia de igualdade. Esse percurso irá permitir o surgimento de um dos temas privilegiados pelo jusnaturalismo moderno - o princípio da igualdade -, constituindo um dos alicerces sobre o qual todo o ideário libertário dos grandes movimentos revolucionários, que atravessaram todo o século XVII, se erigiu.

Consiste, sobretudo, o debate assentado na dicotomia phýsis x nómos em revelar a concepção centrada nos Direitos do Homem, profundamente enraizada na igualdade entre os homens, e que se projeta pelos séculos

1 Doutora em Filosofia do Direito Professora Adjunta da Universidade Católica de Petrópolis - UCPt 
vindouros como um desafio sempre a ser enfrentado e um ideal a ser conquistado.

A oposição phýsis x nómos será o elemento desencadeador para um debate profícuo, hábil em suscitar questões que irão se sedimentar em noções basilares pelos filósofos da Justiça e do Direito. Vale dizer, essa intensa discussão irá exibir os sinais do nascimento do direito primordial à igualdade como direito fundamental do homem.

\section{A ANTÍTESE PHÝSIS X NÓMOS E AS PRIMEIRAS MANIFESTAÇÕES SOBRE OS DIREITOS DO HOMEM}

Em conformidade com a doxografia (de dóxa, que significa opinião, glória) ${ }^{2}$, Arquelau formula, pela primeira vez, a antítese phýsis e nómos ao enunciar que "o justo e o torpe não existem por natureza, e sim por convenção"3. Estamos na Atenas do século V a.C., que, desde Anaxágoras, havia se convertido no principal centro de investigação filosófica, suplantando as antigas colônias da Jônia e da Magna Grécia, berço das especulações físicas e metafísicas dos pré-socráticos. Portanto, Arquelau, inobstante considerado o último "fisiólogo ou físico", segundo a denominação de Aristóteles, convive com o pensamento manifestamente humanista, antropológico, pregado pelos sofistas, provenientes igualmente das cidades dos primeiros pensadores gregos. É no solo ático, no florescer da pólis (cidade-estado) democrática e da cristalização do direito, que a filosofia "da natureza” irá contrapor-se aos novos fundamentos políticos e jurídicos. E

2 . Registre-se que a etimologia da palavra doxografia aponta para uma interpretação mais condizente com o sentido de "glória", pois trata-se de um registro de textos literários, filosóficos, ou teológicos, representativos de uma "gloriosa" produção intelectual, que é compilada e comentada pelos estudiosos. Portanto, não se refere exclusivamente às opiniões exaradas dos especialistas, mas, sobretudo, a uma antologia selecionada dos textos mais importantes de uma determinada época. De fato, a doxografia procura extrair as principais informações acerca da vida e da doutrina dos filósofos e tecer comentários pertinentes. As doxografias mais relevantes encontram-se em Hipólito, Diôgenes Laêrtios e Estobeu. Cf. Jean BRUN, Os pré-socráticos, p. 12.

3. In: Diôgenes LAÊRTIOS, Vidas e doutrinas dos filósofos ilustres, livro II, capítulo 4, 16, p.51. Cf. G.S. KIRK; J.E. RAVEN; M. SCHOFIELD, Os filósofos pré-socráticos: história crítica com selecção de textos, p.409, cuja tradução apresentada é a seguinte: “(...) o bem e o mal existem só por convenção, não por natureza.”. 
o principal argumento sofístico utilizado para solapar a antiga indagação présocrática é a renúncia a encontrar uma identidade permanente, uma substância imutável, identificada no conceito abarcante de phýsis (natureza; processo de nascimento e crescimento; natureza de um ser; princípio originário), que pudesse representar um sentido ordenador ao fluxo caótico da experiência sensível.

Os sofistas penetram na multiplicidade do devir, dele extraindo as inúmeras discordâncias que definem o trajeto do homem como essencialmente agonístico: combates, opiniões díspares, em suma, uma irresístivel vocação heraclitiana para o confronto e para a polarização. Mergulhados na mobilidade do real, eles irão concentrar-se na busca da medida que o próprio homem estabelece para si, recusando a aventurar-se em esferas inatingíveis, ou seja, num tipo de conhecimento inalcançável à mente humana ${ }^{5}$ Trata-se de uma reação ao eleatismo, em especial ao pensamento de Parmênides, que havia desenvolvido o tema da oposição radical entre a razão e a experiência. Os sofistas são partidários da dóxa, do caminho da opinião, da contradita, negando a possibilidade de perquirição de uma verdade absoluta, originária, capaz de revelar a pretensa luminosidade da essência do Ser. Ao revés, a sofística circunscreve sua atuação aos limites da pólis, onde posições antagônicas estão em perpétua luta, constituindo um caminho sombrio que o homem político deve percorrer para se consagrar vitorioso na Cidade-Estado.

O papel do sofista nesse contexto assume um caráter bem determinado: ao renunciar à verdade última perseguida pelo saber filosófico, o sofista abdica de ser sophós (sábio) no sentido etimológico de ser um descobridor ou um iluminador das verdadeiras regiões do Ser, para se converter num mestre de retórica, dotado de técnicas persuasivas, a fim de fazer triunfar a tese que defende. Importa ressaltar que esse significado ligado às habilidades práticas

5. A frase atribuída a Protágoras de que "o homem é a medida de todas as coisas", é-nos transmitida por Platão, em particular no diálogo Teeteto (Ou: Sobre o Conhecimento. Gênero comprobatório), 152 a, in: Diálogos de Platão: Teeteto - Crátilo, p.32, em que Sócrates comenta: “(...) é a definição de Protágoras; por outras palavras ele dizia a mesma coisa. Afirmava que o homem é a medida de todas as coisas, da existência das que existem e da não existência das que não existem. (...)". Em contrapartida, Eugène Dupréel ressalva que Protágoras nunca pronunciou essa frase, embora as suas ideas tenham levado a tal conclusão devido ao fato de ele exaltar o papel do homem como agente determinante, como construtor de seu destino. Na verdade, poder-se-ia dizer que Protágoras talvez nunca tenha escrito essa famosa frase, mas certamente ela deveria fazer parte dos seus discursos, como atestam várias testemunhos, inclusive o de Platão. Cf. Les sophistes: Protagoras, Gorgias, Prodicus, Hippias, p.38. 
está também agregado ao adjetivo sophós e, por conseguinte, a denominação sophistés (sofista) afigura-se pertinente para retratar o professor plenamente habilitado a transmitir toda a herança cultural e filosófica do Grécia e, ao mesmo tempo, habilidoso no manuseio de processos de argumentação com vista à obtenção de resultados eficientes na vida pública e privada ${ }^{6}$.

Abandonada a pretensão especulativa de chegar-se a um consenso com relação à compreensão da phýsis, esboçada pelos pré-socráticos, os sofistas transitam no fluir atordoante do mundo fenomênico, elegendo as convenções humanas, os nómoi (leis escritas) no sentido lato da palavra, como objeto de seu escrutínio e magistério. A opção pelo caminho da dóxa que, na visão de Parmênides, significa habitar "as moradas da Noite", acentua a antítese do Ser pleno, luzente, vislumbrado pela razão: o olhar do sofista estará irremediavelmente sombreado pelo mundo das aparências, das opiniões enganadoras. Por isso, Platão e Aristóteles irão desconsiderar a contribuição filosófica da sofística por ela representar um falso saber.

De fato, Sócrates, no Teeteto, após a citação da célebre definição de Protágoras, que afirma que o homem é a medida de todas as coisas, conclui que para o sofista "aparência e sensação se equivalem com relação ao calor e às coisas do mesmo gênero; tal como cada um as sente, é como elas talvez sejam para essa pessoa", donde a impossibilidade de estabeleceremse critérios universais para classificar o conhecimento de verdadeiro ou falso. Nesta linha de raciocínio, Aristóteles também refere-se aos sofistas em termos depreciativos, desqualificando totalmente as lições transmitidas por esses profissionais da sabedoria. Assim o Estagirita se expressa em Dos argumentos sofisticos: "Ora, para certa gente é mais proveitoso parecer que são sábios do que sê-lo realmente sem o parecer (pois a arte sofística é o simulacro da sabedoria sem a realidade, e o sofista é aquele que faz comércio de uma sabedoria aparente, mas irreal)"'.

Acrescente-se que a repulsa platônica e aristotélica à mensagem

6. Cf. Theodor GOMPERZ, Greek thinkers: a history of ancient philosophy, book III, chapter V, p.416.

7 . Tradução do poema de Parmênides por José Cavalcante de Souza, em Os pré-socráticos, da Coleção Os Pensadores, p.121.

8. 152 c, in: op. cit., p.33. Consulte-se a obra de Eugène Dupréel, acima citada, pp.16-7, sobre esta problemática em Protágoras.

9. Parte 1, 165 a, 20, p.162. Cf. Rodolfo MONDOLFO, O pensamento antigo: história da filosofia greco-romana, v.I, pp.137-8. 
dos sofistas reside no caráter retórico e contraditório das ideias por eles lecionadas. Os sofistas operam por intermédio de refutações, construindo discursos antitéticos (dissoi lógoi) para chegar ao consenso. A retórica caracteriza-se, fundamentalmente, por ser a arte da persuasão, pressupondo a dialética, vale dizer, a controvérsia de opiniões discordantes para alcançar o convencimento da parte contrária no debate. A Platão repugna a técnica argumentativa baseada na dóxa, dominada pelo excesso de conflitos e de imagens distorcidas, distante da verdade essencial dissipadora das aparências. Assim, ele repudia com veemência a palavra enganadora dos mestres da retórica, ao dizer no Fedro: “(...) Mas deixaremos de lado Tísias e Górgias? Êsses descobriram que o provável deve ser mais respeitado que o verdadeiro; chegariam até a provar, pela fôrça da palavra, que as cousas miúdas são grandes e que as grandes são pequenas, que o novo é antigo e que o velho é novo." (grifamos) ${ }^{10}$.

Por seu turno, Aristóteles chama a atenção para a utilização dos poderosos recursos persuasivos dos sofistas, como a criação de antíteses, que funcionam como meio para convencer o adversário na disputa política ou jurídica. Tal é o caso da famosa oposição entre phýsis e nómos, explorada pela sofística nas diversas áreas do conhecimento humano em que sua influência se faz sentir: na praça pública, no tribunal, no teatro. O registro de Aristóteles põe em evidência que a referida antítese constitui um tema bastante debatido, mas, sobretudo, ele pretende ressaltar a doutrina dos contrários advogada pelos sofistas. Cuida-se do emprego operacional de tópoi (lugares-comuns) no confronto e na problematização de posições antinômicas relativas à lei positiva e à lei natural:

A mais ampla coleção de tópicos ou lugares para induzir os homens a fazerem afirmações paradoxais é a que se relaciona com os padrões da natureza e da lei: pois é assim que Cálicles é levado a argumentar no Górgias, e é essa a conclusão que todos os antigos supunham lógica: pois a natureza e a lei (diziam eles) são opostas, e a justiça é uma bela coisa pelos padrões do direito, mas não pelos da natureza. Por conseguinte, diziam eles, o homem cujo juízo se conforma aos padrões da natureza deve ser enfrentado pelos padrões da lei, enquanto o homem que concorda com a lei deve 
ser levado a admitir os fatos da natureza: pois tanto num caso como no outro se pode ser arrastado a fazer afirmações paradoxais. Segundo o ponto de vista deles, o padrão da natureza era o verdadeiro, ao passo que o da lei era a opinião sustentada pela maioria. É evidente, pois, que também eles ou tentavam refutar o oponente, ou levá-lo a fazer afirmações paradoxais, exatamente como fazem os homens de nossos dias. (grifamos). ${ }^{11}$

Importa assinalar que a antiga controvérsia entre phýsis e nómos não se reduz a um expediente retórico aplicado pelos oponentes de uma contenda de acordo com o ponto de vista arguido por cada um. Trata-se de uma questão filosófica da maior relevância para a história do direito cuja atualidade ainda surpreende. No bojo dessa polêmica, o conceito de justiça apresenta variações significativas que revelam a riqueza e a importância do tema para o aperfeiçoamento das instituições políticas e jurídicas. Com efeito, todo o imenso esforço de Platão em definir a Justiça em $A$ república resulta da refutação das teses expostas no Livro I, em especial da defendida por Trasímaco, que tem por base o direito do mais forte, e que constitui uma das postulações dos adeptos da phýsis. Por conseguinte, urge examinar essas duas noções dicotômicas nas principais vertentes que caracterizam o percurso conceitual dessa problemática elaboração sofística.

Convém frisar, preliminarmente, que a distinção entre phýsis e nómos decorre da separação entre o mundo da natureza e o mundo da cultura, captada com clareza pelos sofistas. Na filosofia naturalista anterior ocorre uma acentuada tendência a identificar as leis naturais com a regularidade observada na vida do homem no que diz respeito à sedimentação de normas costumeiras e de princípios norteadores de justiça. Vale dizer, o homem desincumbese da tarefa de ordenar a convivência em sociedade estabelecendo códigos de conduta de validade permanente; permanece, no entanto, impotente para compreender as leis que regem a natureza, pois, consoante a apreciação de John Burnet, "o homem vivia dentro de um círculo mágico de lei e costume, e fora dele ficava um mundo desordenado."12 Quando os primeiros filósofos

11 .Dos argumentos sofisticos, 12, 173 a, 10-20, p.179. Cf. G.B KERFERD, The sophist movement, pp.113-4. Consulte-se a respeito da questão da tópica e da argumentação, Tercio Sampaio FERRAZ JUNIOR, Introdução ao estudo do direito: técnica, decisão, dominação, pp.295-302. 
elaboram as primeiras teorias sobre os mistérios do universo, verifica-se um prolongamento dos conceitos que circulam no intercâmbio cultural para os fenômenos de ordem natural; assim Anaximandro formula uma lei universal para a natureza empregando uma terminologia legal em paridade com os procedimentos jurídicos inspirados em Sólon; da mesma forma Heráclito postula uma medida cósmica regulatória para todos os processos físicos e humanos fixada na ideia de uma justiça infalível: "Hélio não transporá seus limites; senão, as Erínias que a Diké assistem, irão encontrá-1o."13

Os sofistas irão romper com a identificação pretendida pelos présocráticos e provocar a inevitável cisão entre as duas esferas: a natureza e a lei são instâncias pertencentes a domínios diferentes. A antítese, contudo, apresenta graus variáveis de adesão aos dois pólos da oposição, ou seja, alguns pensadores tenderão a dar suporte incondicional à phýsis em detrimento da convenção ao passo que outros se posicionarão favoráveis à supremacia do nómos ${ }^{14}$.

Em primeiro lugar, faz-se necessário mencionar dois fragmentos de autoria do sofista Antifo que traz à tona trechos esclarecedores acerca da separação entre a natureza e a convenção. A Antifo são atribuídos alguns tratados que versam sobre física e ética, sendo importante assinalar em especial o intitulado "Sobre a Verdade", em que ele desenvolve a concepção de uma justiça natural contraposta à lei imposta pela cidade. $\mathrm{O}$ sentido de natureza usado pelo sofista apresenta duas acepções: serve para desautorizar as leis emanadas do poder estatal devido à arbitrariedade das convenções em face das imperiosas necessidades e da inexorabilidade das leis naturais; e para desacreditar as desigualdades perpetradas em nome de superioridades - arbitrárias - proclamadas por certas classes sociais ou povos como, por exemplo, a distinção feita entre os gregos e os "bárbaros", o que revela o alcance humanitário do texto, decerto inédito e revolucionário na história das

"mundo desordenado" ("the world around him still seemed lawless") põe em destaque justamente a ausência de uma regulação aplicável ao mundo da natureza; a tradução utilizada encontra-se no livro Teoria política grega - Platão e seus predecessores, de Sir Ernest Barker, p.64.

13

.Traduzido (fragmento 94) por Eudoro de Sousa, no artigo Fontes da história da filosofia antiga, publicado na Revista Brasileira de Filosofia, v. IV, fascículo 2, p.314. Cf. John BURNET, Op. cit., p.86.

.Cf. Sir Ernest BARKER, Op. cit., pp.63-4; Rodolfo MONDOLFO, op. cit., p.154. 
ideias neste aspecto específico. De fato, com relação ao segundo fragmento, cabe sublinhar a importância desse texto como revelador dos direitos humanos, tal qual divisada por Fábio Konder Comparato em $A$ afirmação histórica dos direitos humanos. Vejamos algumas passagens do referido tratado (fragmentos I e II), que corroboram o pensamento francamente naturalista de Antifo: $I$

A Justiça (no entendimento comum) consiste em não transgredir (ou melhor, em não se fazer conhecido como transgressor de) qualquer uma das normas legais (nómina) do estado onde se vive como cidadão. É possível, portanto, praticar a Justiça da forma mais vantajosa se se prega o respeito às leis na presença de testemunhas; na ausência delas, porém, se obedece aos ditames da Natureza (tà tes fúseos). A razão disto é a seguinte: as leis (tà ton nómon) são adventícias; as regras da Natureza são inevitáveis (e inatas).

As leis são criadas por convenção (omologethénta), não pela Natureza (fúnta), o que é o contrário do que acontece com as regras naturais. Pode-se assim transgredir as leis sem vergonha e sem castigo quando não se está sendo observado; a vergonha e o castigo decorrem apenas daquela observação. Coisa diferente acontece com a transgressão das regras naturais. Se alguém as infringe além de um certo limite, as conseqüências funestas que disso advêm não aumentam com a circunstância de que o infrator foi observado, nem diminuem no caso contrário. A injúria que recebemos como penalidade pela transgressão não provêm de alguma opinião (dià dóxan), mas de fatos reais (di'alétheian).

II

Reverenciamos e veneramos (os que nascem de uma linhagem importante); mas os que nascem em berço humilde não recebem nossa veneração, nem a nossa reverência. (...) Nossas faculdades naturais são absolutamente as mesmas, quer sejamos gregos ou bárbaros. Podemos observar as características de qualquer das faculdades que pela natureza são necessárias a todos os homens ... Nenhum de nós, grego ou bárbaro, (tem essas características de forma 
especial). Todos respiramos o mesmo ar, pelas narinas e pela boca. ${ }^{15}$

Antifo enquadra-se, por conseguinte, na vertente postulada pelos defensores da phýsis. Os fragmentos demonstram com nitidez que as leis da Cidade são convenções arbitrariamente formuladas pelos homens, pertencendo, portanto, à esfera da dóxa, da aparência. Por oposição, as leis da natureza são necessárias, ou seja, constituem o reino da verdade, da realidade ("di'alétheian") na medida em que qualquer violação às suas regras provoca uma reação inevitável ao transgressor: a sua punição é inexorável. São essas leis naturais que devem ser respeitadas e obedecidas. Os nómoi, ao revés, impõem-se pela coerção, são contrários à natureza e, dessa forma, podem ser infringidos desde que se preserve a aparência de não os terem transgredido; o castigo, nesse ludíbrio legal, não sobrevém pois as leis humanas são apenas artifícios criados para disciplinar a vida do homem no convívio social: a ficção não imita a natureza, que representa, em última instância, a medida definidora do direito ${ }^{16}$.

Essa concepção conduz a uma relativização da norma jurídica, contribuindo para desmoronar o ideal do estado jurídico que preconiza o respeito às prescrições normativas como forma de efetivar a igualdade democrática e salvaguardar a liberdade dos homens livres. Os sofistas percebem que a mera ordenação das leis não garante sua observância

15 .Tradução extraída da obra de Sir Ernest Barker, citada acima, pp.89-90. Convém registrar que os fragmentos do sofista Antifo foram descobertos no início do século passado e obtiveram enorme repercussão pela importância de suas colocações sobre o tema da antítese phýsis x nómos. Vale mencionar um trecho da tradução apresentada por Rodolfo Mondolfo no livro referido atrás, p.155, em razão da oposição entre a lei e a natureza, acentuada pelo contraste entre artificial e necessário: “(...) Pois, enquanto os da lei são artificiais, os da natureza são necessários. Os da lei convencionais e não naturais; os da natureza naturais e não convencionais. (...). Consultem-se os fragmentos em Maria Timpanaro Cardini, compiladora de I sofisti: frammenti e testimonianze, pp.118-21, e igualmente os seguintes autores: além de Sir Ernest BARKER, Op. cit., pp.72-5, e Rodolfo MONDOLFO, Op. cit., pp.154-6, ver W.K.C GUTHRIE,. The 'Nomos'-'Physis' Antithesis in Morals and Politics. In: The sophists, pp.107-115; Werner JAEGER, Paidéia: a formação do homem grego, pp.263-4; G.B KERFERD, The sophistic movement, pp.115-6. Fábio Konder COMPARATO, p.15 historique a une étude de la philosophie platonicienne, pp.358-61. 
espontânea e que esse processo pode implicar contradições entre o padrão idealizado de Justiça e as conveniências políticas que exigem ações mais eficazes e incisivas, por vezes antagônicas aos princípios morais consagrados. Ademais, a lei passa a ser concebida como heterônoma, de foro externo, especificando os atos permissíveis e as abstenções a partir dos quais o homem deve pautar a sua conduta. Conforme analisa Werner Jaeger, é necessário que uma nova fundamentação ética desponte a fim de restaurar a validade do nómos, porquanto no entendimento de Antifo

a lei carece, pois, de força compulsiva absoluta. É concebida como algo totalmente exterior. Não é um conhecimento gravado no interior do Homem, mas um limite que não pode ser transgredido. Mas, se falta a coação interna, se a justiça consiste só na legalidade externa dos usos de comportamento e no evitar o prejuízo da pena, então não há ocasião nem perigo de faltar às aparências e em que não existem testemunhas da nossa ação. É este, com efeito, o ponto em que para Antifonte reside a diferença essencial entre a norma jurídica e a da natureza. ${ }^{17}$

Em razão da ênfase na legalidade externa, Platão buscará solucionar o problema suscitado por Antifo criando a fábula do anel de Giges, narrada por Gláucon no início do livro II de A república. Trata-se de dar uma resposta ao desafio lançado pelo sofista para violar a lei na ausência de testemunhas que pudessem incriminar o infrator; o anel de Giges concede o poder de tornar invisível o seu possuidor, insuscetível, assim, de censura ou de condenação caso pratique alguma ação contrária aos preceitos morais ou jurídicos. Essa invisibilidade tornaria impraticável distinguir o homem justo do injusto, abrindo um terreno fértil para a disseminação da injustiça: o ponto crucial da questão reside em parecer justo. Platão pretende demonstrar o equívoco do raciocínio formulado pelo sofista, provando que o constrangimento da lei é necessário apenas para o homem injusto, uma vez que o virtuoso não cometerá desatinos mesmo na posse de algum poder mágico que lhe resguardasse a

17 .Op. cit., p.264. Consultem-se os capítulos XVII, Natureza e Cultura, pp.240-56, e o XVIII, Leis naturais e leis éticas: teoria e prática, pp.257-70, do livro Filosofia do direito, de Miguel Reale, indispensáveis para uma perfeita compreensão das diferenças fundamentais entre natureza e cultura. 
imagem de homem justo, pois este indivíduo está essencialmente subordinado aos ditames da justiça; ele, diz-nos Gláucon, "não quer parecer bom, mas sê-lo" $" 18$, em direta alusão às palavras de Ésquilo em os Sete contra Tebas. A verdade para Platão não admite disfarces nem artifícios encobridores da verdadeira natureza humana.

No que concerne à crítica de Antifo à desigualdade entre os povos, observa-se em Hípias a mesma aderência à phýsis, usada como recurso argumentativo para provar a igualdade inata - e não perante à lei - de todos os homens. Cuida-se de um manifesto repúdio a qualquer tipo de discrímen com base em diferenças étnicas falsamente estabelecidas por ideias preconcebidas -opiniões - próprias de cada grupo social e não por critérios -verdadeiros - consentâneos com a forma igualitária eleita pela natureza para moldar a humanidade. Caminha-se para um sentido cosmopolista de convivência humana e para uma visão universalista da lei natural, que sobrepuja as particularidades dos nómoi restritos a cada comunidade. Hípias exprime esse "princípio de igualdade e fraternidade humana"19, como corretamente define Rodolfo Moldolfo, em celebrada passagem no Protágoras, para demonstrar a controvérsia entre as leis não-escritas e as estatuídas pelo poder estatal, representação teatral da antítese phýsis x nómos:

(...) Senhores aqui reunidos, sou de opinião que todos nós somos parentes, amigos e concidadãos, não por força da lei $(\nu \dot{o} \mu \hat{\omega})$, mas pela natureza $(\phi i \sigma \in \iota)$; porque o semelhante é por natureza ( $\phi \dot{v} \sigma \in \iota)$ igual ao semelhante, ao passo que a lei ( $\nu$ ó $\mu)$, como tirana que é dos homens, violenta muitas vezes a natureza $(\phi \dot{\jmath} \sigma \iota \nu) .(\ldots)^{20}$.

18 . PLATÃO. A república, livro II, 361 b, p.59. A narração do anel de Giges aparece nas seguintes partes de $A$ República: livro II, 359 d, e, pp.56-7, e 360 a,b,c,d, pp.57-8, e segundo nota da tradutora, Maria Helena da Rocha Pereira, a história de Giges registra que ele tornou-se rei da Lídia, após ter assassinado o rei que o antecedeu e de ter casado com a viúva; a fábula do anel foi construção de Platão. Cf. Werner JAEGER, op. cit., pp.265-6; W.K.C. GUTHRIE, op. cit., pp. 98 e 111.

19 . Op. cit., p.157.

20

.Protágoras (Ou: Os Sofistas. Gênero demonstrativo), 337 d, in: PLATÃO. Diálogos de Platão: Protágoras - Górgias - O Banquete - Fedão, p.77. Ver a tradução francesa bilíngüe (francês e grego) de Alfred Croiset, com a colaboração de Louis Bodin in PLATON. Oeuvres complètes, tome III, I ${ }^{\text {re }}$ partie, p.55; e Werner JAEGER, op.cit., pp.262. Cf. W.K.C. GUTHRIE, op. cit., pp.118-9; Wilhelm WINDELBAND, Historia de la filosofia antigua, p.124; Eduard ZELLER, Outlines of the history of Greek philosophy, p.90. 
Eurípides transmite essa mensagem de igualitarismo em As fenícias, através do apelo de Jocasta para que seus filhos, Etéocles e Polinices, cessem a querela pela disputa do reino de Tebas, vez que "é melhor reverenciar a Eqüidade/ que liga para sempre amigos a amigos/ povos a povos, aliados a aliados,/ pois ela sempre foi para os seres humanos/ o esteio principal da estabilidade" 21 . Ponderação rejeitada por Etéocles, que havia declarado a relatividade das convenções humanas, donde a inexistência de um princípio igualitário de validade universal capaz de congregar todos os homens: "Mas não existe entre os mortais conceito fixo/ de 'semelhante' nem de 'igual'; estas noções/ são somente palavras sem realidade."22

E é com essa visão realista que Tucídides irá registrar a superioridade dos atenienses nas suas relações com os outros povos, sobressaindo-se a igualdade baseada na força e no poder, e a preponderância da justiça da eficácia para garantir a hegemonia de Atenas na Liga de Delos. Importa realçar que os atenienses expressam posições incongruentes com relação à concepção de Justiça e de igualdade: na pólis predomina o respeito ao padrão tradicional de justiça e à distribuição equitativa de bens entre os cidadãos livres, enquanto que fora da Cidade prevalece o emprego da violência pelos dominadores. Tucídides narra, com acuidade, essa contradição no episódio de Melos - que não participa da Liga e da guerra do Peloponeso - em que os atenienses exigem a submissão da ilha, agindo com truculência em face da resistência dos mélios; os discursos abaixo transcritos revelam, com contundência, o abandono dos ideais de Justiça em face das exigências da conquista e da consolidação do império ateniense:

(...) Não fomos nós os primeiros autores disto, mas sempre foi estabelecido, que o mais débil está sujeito ao mais forte: cremos dignos (de dominar) e vós também o acreditastes até que agora, consultando a vossa utilidade, vindes falar do justo: a que ninguém foi induzido a renunciar quando a fortuna lhe oferece uma vantagem a conquistar pela violência ... Quem pode recorrer à violência não tem necessidade de apelar para a justiça. (...)" (grifamos). 
“(...) Que, nos conflitos humanos, só se entra em acordo quanto à justiça quando a necessidade é igual; enquanto os que têm supremacia de poder exigem tudo o que puderem, os mais fracos cedem às condições que forem impostas. ${ }^{23}$

Nesse sentido, a posição defendida por Cálicles no Górgias, de Platão, reflete uma das concepções mais extremas sustentadas pelos partidários da phýsis. Cuida-se da doutrina direito do mais forte que repele completamente o conceito de legalidade e de igualdade. Com efeito, Cálicles considera as leis escudos protetores para os fracos que, assim, conseguem nivelar-se aos que, por natureza, lhes são superiores em força e inteligência. Por conseguinte, a desigualdade constitui a regra, não podendo as limitações legais, artificialmente impostas, impedir que os aquinhoados com qualidades excepcionais - por direito natural - possam exercer os seus plenos poderes sobre os medíocres.

Cálicles é, indubitavelmente, um precursor da teoria naturalista e competitiva do survival of the fittest, princípio que parece inextirpável dos corações e mentes dos homens; considere-se, por exemplo, a ordem de $\mathrm{Mr}$. Kurtz, personagem criado por Joseph Conrad em $O$ coração das trevas: "Exterminem todos os bárbaros!"”24, reflexo da brutal lógica do imperialismo que há séculos configura vergonhosa nódoa para a humanidade. Vejamos como Cálicles expõe suas ideias no diálogo que leva o nome do sofista Górgias, este, na verdade, opositor ao direito do mais forte contrário à legalidade, vez que na Apologia de Palamede, ele se expressa favorável às

23 .The Peloponnesian War, I, 76, pp.44-5; V, 89, p.365. Para o trecho do primeiro livro, utilizamos a tradução apresentada por Rodolfo Mondolfo, na obra já citada, p.157; com relação à passagem do livro $\mathrm{V}$, recorremos à tradução que consta do livro de Alasdair MacIntyre, intitulado Justiça de quem? Qual racionalidade?, p.65. É importante explicar, consoante MacIntyre, p.63, que a Liga de Delos tinha sido concebida originariamente para fortalecer a proteção naval contra os persas, tendo sido assim reconhecida pelos seus membros; no entanto, posteriormente, os atenienses utilizaram-se deste motivo para construir o seu império, desviando todo o tesouro arrecadado da Liga para Atenas. Cf. W.K.C. GUTHRIE, op. cit., pp.85-6.

24 .Joseph CONRAD, Youth; Heart of darkness, p.130 (" Exterminate all the brutes!"'). Cf. NEWTON CARLOS. Kurtz e Kissinger. Jornal do Brasil, de 14-12-1998, p.11. 
leis escritas que funcionam como guardiães da justiçç ${ }^{25}$, antípoda da justiça natural na versão violenta propalada por Cálicles:

(...) Tu [Sócrates] aprendeste esse ardil e trapaceias o debate, reperguntando em termos de natureza quando se responde em termos de lei, e em termos de lei quando se responde em termos de natureza. (...) Com efeito, isso de sofrer injustiça nem é próprio de homem, senão de algum escravo, para quem melhor é morrer do que viver, incapaz de valer a si mesmo ou a outrem de sua estima, quando injustiçado e ultrajado. A lei, a meu ver, quem a cria são os homens fracos, a maioria. É em vista de si mesmos e de suas próprias conveniências que eles criam as leis, formulam os louvores e os vitupérios; como temem aos homens mais robustos e capazes de pravelecer (sic) sobre eles, para não serem sobrepujados, declaram vergonhoso e iníquo prevalecer e que a injustiça consiste nisso, em procurar avantajar-se aos outros; é uma satisfação para eles, creio eu, inferiores que são, acharem-se no mesmo nível. Por isso a lei declara iníquo e vergonhoso o tentame de pravelecer (sic) à maioria e chamam a isso praticar injustiça; mas a própria natureza, a meu ver, demonstra, de outro lado, que é justo prevaleça o melhor sobre o pior, quem pode mais, sobre quem pode menos. (...) Nasça, porém, um homem de índole assaz forte e ele, no meu entender, há de sacudir de si e romper todas essas injunções, safarse delas, calcar aos pés nossos escritos, sortilégios, encantamentos e mais leis contrárias à natureza, pôr-se de pé e, de servo que era, assomar como nosso amo; brilhará, então, esplendoroso, o direito da natureza. $(\ldots)^{26}$

25 .Cf. Górgia, no fragmento assinalado, 30, inserto no livro organizado por Maria Timpanaro Cardini, obra citada, p.67, que, na versão italiana assim se apresenta: “(...) e le leggi scritte custodi della giustizia (...). Cf. OSTWALD, Martin Nomos and the beginnings of the Athenian democracy, p.51. seguintes referências bibliográficas acerca da posição de Cálicles: Sir Ernest BARKER, op. cit., pp.76-8; W.K.C. GUTHRIE, op. cit., pp.117-9; Rodolfo MONDOLFO, op. cit., pp.1567. 
Observe-se que Cálicles inicia sua exposição criticando o método empregado por Sócrates no debate, que se utiliza da antítese phýsis $\mathrm{x}$ nómos na argumentação sem definir as distinções reais, adotando, como Aristóteles adverte, a tese mais conveniente para persuadir o oponente ${ }^{27}$. Todavia, Platão empenha-se em denunciar a falsidade das teorias sofísticas e, nas Leis, resume a pregação do direito do mais forte propagada por alguns sofistas: "Eis a doutrina, meus caros, que nossos sábios impingem aos moços, em prosa e verso, afirmando ser mais do que justo tudo o que é imposto pela força vitoriosa." ${ }^{28}$ Além de Cálicles, há outros notórios adeptos da phýsis propensos a relacionar o direito e a justiça com a força; na República, Trasímaco, no livro I, embora sem mencionar os termos da controvérsia entre a lei e a natureza, defende a tese de que o direito reproduz os interesses daqueles que detêm o poder, ou seja, dos que determinam pela força a legislação que se lhes afigura mais conveniente visando à proteção dos bens por eles estimados como valiosos. Vale dizer, Trasímaco considera válida somente a norma estatal, que representa a vontade legisladora dos "poderes constituídos", quer seja ela democrática ou monárquica, quer atenda aos reclamos dos fracos ou dos fortes. Trasímaco é a prefiguração do Leviatã devido à identificação da justiça com o poder soberano. A apologia de Trasímaco é manifestação desalentada do reconhecimento do direito do mais forte:

Certamente que cada governo estabelece as leis de acordo com a sua conveniência: a democracia, leis democráticas; a monarquia, monárquicas; e os outros, da mesma maneira. Uma vez promulgadas essas leis, fazem saber que é justo para os governos aquilo que lhes convém, e castigam os transgressores, a título de que violaram a lei e cometeram uma injustiça. Aqui tens, meu excelente amigo, aquilo que eu quero dizer, ao afirmar que há um só modelo de justiça em todos os Estados - o que convém aos poderes constituídos. Ora estes é que detêm a força. De onde resulta, para quem pensar correctamente, que a justiça é a mesma em toda

$27 \quad$.Ver nota 10 acima.

28 .Livro X, 890 a, p.319, das Leis: (Sobre a legislação. Gênero político). In: Platão. Diálogos de Platão: Leis e Epínomis. 
a parte: a conveniência do mais forte. ${ }^{29}$

Deve-se ponderar que a desilusão de Trasímaco ao reivindicar um conceito de grande impacto demolidor provém da verificação de que o ideal de justiça é inaplicável à realidade, onde prevalece o recurso a mecanismos coercitivos, monopolizados pelos detentores do poder, constituindo o padrão do direito e da política. Na percuciente análise de W.K.C. Guthrie, a verdadeira intenção de Trasímaco é "desmascarar a hipocrisia e mostrar como o sentido de justiça tem sido deturpado" "30; de fato, cabe razão a Guthrie se trouxermos à colação o fragmento 9, em que o sofista reconhece a justiça como o valor mais precioso: " os Deuses não se ocupam das cousas humanas; pois do contrário não se teriam descuidado do maior dos bens humanos: a justiça; com efeito, vemos que os homens dela não se servem." $(\text { grifamos) })^{31}$.

Ao afirmar que a justiça está atrelada aos poderosos de maneira inescapável, Trasímaco e Cálicles repetem, em tom mais agressivo, a fábula do gavião e do rouxinol contada por Hesíodo em Os trabalhos e os dias, que serve de advertência ao seu irmão Perses contra os abusos cometidos contra a justiça soberana, divina, que rege a vida dos homens. Importa acentuar que a imagística animalesca é extremamente apropriada para se estabelecer um paralelo com os impulsos irrefreáveis de origem natural, pertencentes ao âmbito da phýsis, proclamados pelos cultores do direito natural de tendência radical, e satirizados por Aristófanes como, por exemplo, em As nuvens. Convém contrastar a antiga versão hesiódica com a dramatização cômica da concepção que conduz ao caminho da desumanização:

(...)

Assim disse o gavião ao rouxinol de colorido colo no muito alto das nuvens levando-o cravado nas garras;

29

.PLATÃO, A república, livro I, 338e; 339a, p.24. Cabe examinar as duas primeiras partes, denominadas Do Homem e Do Estado, da obra de Thomas Hobbes, Leviatã ou matéria, forma e poder de um estado eclesiástico e civil, pp.7-218. Cf. Sir Ernest BARKER, op. cit., p.77; W.K.C. GUTHRIE, op. cit., pp.88-90; KERFERD, G.B. Op. cit., p.121.

30

.Op. cit., p.92, e também pp.93-4.

31 .Tradução constante do livro de Rodolfo Mondolfo, op. cit., p.156; fragmento 9 apresentado por Maria Timpanaro Cardini, op. cit., p.95, in verbis: "che gli dei non badano alle cose umane; altrimenti non avrebbero trascurato il massimo dei beni umani, la giustizia; vediamo infatti che gli uomini non l'applicano mai." 
ele miserável varado todo por recurvadas garras gemia enquanto o outro prepotente ia lhe dizendo: 'Desafortunado, o que gritas? Tem a ti um bem mais forte;

tu irás por onde eu te levar, mesmo sendo bom cantor; alimento, se quiser, de ti farei ou até te soltarei. Insensato quem com mais fortes queira medir-se, de vitória é privado e sofre, além de penas, vexame'. $(\ldots)^{32}$

Conforme mencionado, Trasímaco transmite sua mensagem sem referir-se à antítese entre a natureza e a convenção. Evidentemente, sua colocação se ajusta na dicotomia, já que ele é um postulante do direito natural do mais forte. Comprova-se esta asserção pelas considerações expendidas por Gláucon, no livro II de $A$ república, que não hesita em inserir o problema proposto por Trasímaco nos termos da aludida oposição, consoante se pode atestar na seguinte afirmação: "Apanhá-lo-emos, ao justo, a caminhar para a mesma meta que o injusto, devido à ambição, coisa que toda a criatura está por natureza disposta a procurar alcançar como um bem; mas, por convenção, é forçada a respeitar a igualdade." ${ }^{33}$ Cabe esclarecer que esse trecho pertence à narração do anel de Giges, relatado por Gláucon para evidenciar um outro ângulo da problemática discussão relacionada à phýsis.

De fato, os irmãos Gláucon e Adimanto, ainda perplexos ante a crueza e veemência da argumentação de Trasímaco, travam com Sócrates um intenso diálogo para definir a essência da justiça e indagar sobre os efeitos produzidos que permitem qualificá-la como um bem, quiçá reconhecida em algum ser humano ${ }^{34}$. A provocação de Gláucon e Adimanto reflete a concepção de justiça na esteira do sofista Antifo, intensificada a valorização no utilitarismo, no interesse pessoal, na medida em que o homem busca, a todo custo, realizar as suas ambições e atender às suas necessidades naturais: as leis são simples convenções que podem ser quebradas se o indivíduo dispuser de astúcia suficiente para lograr atingir suas metas. $\mathrm{Na}$ visão de Gláucon, o homem tem uma inclinação inata a praticar ações injustas, caso

32 .HESÍODO, Os trabalhos e os dias, v.203-211, pp.37-9. Cf. Pierre-Maxime SCHUHL, op.cit., pp.362-3. 
consiga desembaraçar-se dos grilhões legais, pois a injustiça é, de longe, "mais vantajosa" 35 para a obtenção de todos os bens almejados. Opinião compartilhada por Adimanto que afirma que "se formos justos, só estaremos livres de castigo por parte dos deuses, mas afastaríamos assim os lucros provenientes da injustiça." 36

Em total contraposição aos defensores da phýsis posiciona-se Protágoras, justificando a absoluta submissão às leis como a melhor forma de o homem sair do estado natural, reinado do homo homini lupus delineado posteriormente por Hobbes ${ }^{37}$, em que uma série ininterrupta de hostilidades expõe o homem a uma guerra interminável. Para sofrear esse quadro caótico de tendências bestiais e belicosas, urge que seja elaborado um repertório de normas coercitivas para coordenar as paixões humanas, esboçando-se, assim, um projeto de contrato social.

É nesta direção que Protágoras caminha ao apresentar o mito sobre a origem da cultura, em que uma ordenação divina envia aos homens o dom de aidós (respeito, pudor) e de dike (justiça) como solução definitiva para a sobrevivência humana. Ressalte-se que essas qualidades superiores, outorgadas por um poder supremo, são conferidas a todos os homens, constituindo um traço distintivo que os eleva acima da condição animal, vale dizer, coloca-os na direção da construção da Cidade-Estado, assentada em valores morais e jurídicos, consoante deixa claro Protágoras na narração do mito:

(...) À vista disso, experimentaram [os homens] reunirse, fundando cidades, para poderem sobreviver. Mas, quando se juntavam, justamente por carecerem da arte política, causavam-se danos recíprocos, com o que voltavam a dispersar-se e a serem destruídos como antes. Preocupado Zeus com o futuro de nossa geração, não viesse ela a desaparecer de todo, mandou que Hermes levasse aos homens o pudor e a justiça, como princípio ordenador das cidades e laço de aproximação

35 .PLATÃO, A república, livro II, 360d, p.58. Cf. W.K.C. GUTHRIE, op. cit., pp.979.

36 .PLATÃO, A república, livro II, 366a, p.67.

37 Cf. o Capítulo XIII do Leviatã ou matéria, forma e poder de um estado eclesiástico e civil, pp.74-77. 
entre os homens. (...)"38

A concepção de justiça de Protágoras caracteriza-se pelo tentame de unificar os termos antitéticos da antítese phýsis x nómos, ou seja, ele defende a obediência às leis estatuídas pela necessidade de convivência e colaboração pacíficas; no entanto, os nómoi não são convenções estabelecidas pelo arbítrio do homem para a consecução de seus interesses pessoais ou de classe: são pelos deuses sancionados e inspirados em princípios éticos fundamentais para a formação da mais elevada consciência moral e jurídica. Sir Ernest Barker atribui a Protágoras a qualificação de "apóstolo do Estado, que pregava a igualdade dos seus membros e a santidade da Lei." ${ }^{39}$. Cumpre consignar que esse espírito de defesa das leis constitui uma das peculiaridades do pensamento grego, encarnado em diversas expressões literárias e filosóficas, tal como é ilustrado por Heródoto pelas palavras pronunciadas por Demáratos no diálogo com Xerxes: "De fato, sendo livres eles [os helenos] não são livres em tudo; eles têm um déspota - a lei - mais respeitado pelos lacedemônios que tu por teus súditos" (grifamos) ${ }^{40}$.

Protágoras não representa uma voz isolada na candente disputa pela supremacia do nómos como forma de pacificar a violência espelhada no estado de natureza. Os fragmentos constantes do "Anônimo de Jâmblico" fornecem subsídios significativos para o encaminhamento de uma concepção que efetue a necessária articulação entre a justiça, considerada o fundamento natural para a formação das instituições humanas, e as leis produzidas para manter a coesão entre os homens. Ressalte-se que o sentimento de justiça, doado pela natureza, representa a virtude mais importante para a tutela dos bens por eles prezados. Em outros termos, a justiça constitui o elemento unificador mais eficiente, ao banir a barbárie e preservar a vida em núcleos

38 .PlATÃO, Protágoras (Ou: Os Sofistas. Gênero demonstrativo), 322b,c, p.58. Cf. Sir Ernest. BARKER, op. cit., p.70; W.K.C. GUTHRIE, Os filósofos gregos de Tales a Aristóteles, p.58, e The 'Nomos'-'Physis' Antithesis in Morals and Politics. In: The sophists, pp.66-9; G.B. KERFERD, op. cit., p.126; Rodolfo MONDOLFO, op.cit., pp.190 e 472.

$$
\text { .Op. cit., p.70. }
$$

40 .História, livro VII, 104, p.368. Cf. GUTHRIE, W.K.C. The 'Nomos'-'Physis' Antithesis in Morals and Politics. In: . The sophists, p.69. Esclareça-se que Demáratos havia sido deposto da condição de rei dos espartanos e encontrava-se exilado sob a proteção de Xerxes. 
políticos organizados sob o império da lei. Logo, os efeitos da injustiça que Gláucon e Adimanto aspiram a conhecer - devem ser evitados, pois causam conseqüências nocivas para o corpo político, sendo desvantajoso para o homem tanto no plano particular quanto no geral. Convém transcrever alguns trechos do "Anônimo de Jâmblico" para demonstrar a busca de uma posição conciliatória entre phýsis e nómos:

(...) Considerando que os homens, por natureza, não podem viver isolados, e, impelidos pela necessidade, ajustaram-se entre si e encontraram assim tôda a vida e as indústrias úteis a esta, mas não lhes era possível manter-se reunidos e viver sem leis (pois permanecer assim lhes era mais penoso do que viver isolados), por tôdas estas necessidades, pois, a lei e o justo devem reinar entre os homens, nem de modo algum dêles se afastar: pois estas cousas foram dadas pela natureza. (...)" (6. p.100, 5, 1);

(...) Isso será possível, pois, tornando-se tutor das leis e da justiça: elas mantêm unidas as cidades e os homens. (3. p.97, 16, 6);

(...) Dêsse modo, parece que também a força, que entretanto é força, sòmente se salva com a lei e a justiça. (6. p.100, 5. 5). ${ }^{41}$

\section{CONCLUSÃO}

A conclusão que se impõe é que o exame sobre os fundamentos do nosso pensar e agir jurídicos deve iniciar-se na Grécia antiga. Apesar da

41 .Tradução dos fragmentos a partir do texto de Rodolfo Mondolfo. In: $O$ pensamento antigo: história da filosofia greco-romana, v.I, pp.152-3. Ver a compilação de Maria Timpanaro Cardini, op. cit., pp.167, 166 e 168, de acordo com a extratos de de uma ordem em que os fragmentos foram apresentados. Cabe informar que o "Anônimo de Jâmblico" constitui obra sofística, conservados pelo neoplatônico Jâmblico, segundo esclarece Eduard Zeller, em Outlines of the history of Greek philosophy, p.90. Cf. também G.B. KERFERD, op.cit., p.126. 
distância que nos separa, esse caminho é fascinante e instigante. Recorrer aos teóricos da Justiça e do Direito é uma passagem obrigatória para a perfeita compreensão dos alicerces conceituais que embasam a construção jurídica do mundo ocidental. Com efeito, o fio condutor para nossa reflexão sobre o aparecimento da ideia de igualdade, um dos pilares da construção dos direitos humanos, foi o debate vigoroso especialmente travado entre os sofistas sobre a dicotomia phýsis x nómos. Essa discussão inicia-se com os pré-socráticos e atinge maior densidade filosófica nos escritos de Platão e Aristóteles.

Justifica-se esse retorno aos pensadores clássicos um instrumental adequado para estabelecer a conexão entre o pensar fundacional, elaborado com tanta profundidade pelos teóricos da Justiça e do Direito, e o presente, logrando alcançar o revigoramento das nossas tradições jurídicas. E buscar nesses fundamentos as origens de um pensamento constitutivo dos Direitos Humanos, legado que exige uma reconstrução permanente da humanidade. 


\section{Referências Bibliográficas:}

ARISTÓFANES. As nuvens. In: . As nuvens; Só para mulheres; Um deus chamado dinheiro. Tradução do grego, introdução e notas de Mário da Gama Kury. Rio de Janeiro: Jorge Zahar, p. 11-103, 1995. (A Comédia Grega).

ARISTÓTELES. Dos argumentos sofísticos. In: . Tópicos; Dos argumentos sofísticos; Metafísica; Ética a Nicômaco; Poética. Trad. Leonel Vallandro; Gerd Bornheim da versão inglesa de W.A. Pickard - Cambridge. São Paulo: Abril Cultural, p.159-203, 1973. (Os Pensadores).

. Metafisica. Trad. Leonel Vallandro. Porto Alegre: Globo, 1969. (Biblioteca dos Séculos).

BARKER, Sir Ernest. Teoria política grega-Platão e seus predecessores. 2 ed. Trad. Sérgio Bath. Brasília: Editora Universidade de Brasília, 1978. (Coleção Pensamento Político, 2). BURNET, John. Greek philosophy: Thales to Plato. London: The Macmillan Press, 1981.

BRUN, Jean. Os pré-socráticos. Trad. Armindo Rodrigues. Lisboa: Edições 70, 1991. (Biblioteca Básica de Filosofia).

CASSIN, Barbara. L'effet sophistique. [Paris]: Gallimard, 1995. (NRF Essais).

COMPARATO, Fábio Konder. A afirmação histórica dos direitos humanos. 5 ed., rev. e ampl. São Paulo: Saraiva, 2007.

CORNFORD, Francis MacDonald. Before and after Socrates. Cambridge: University Press, 1966.

DUPRÉ, P. Encyclopédie des citations. Comité de rédaction sous la présidence de Fernand Keller. Paris: Éditions de Trévise, 1959.

DUPRÉEL, Eugène. Les sophistes: Protagoras, Gorgias, Prodicus, Hippias. Neuchâtel: Éditions du Griffon, 1980. (Bibliothèque Scientifique, 14 Philosophie et Histoire). 
ESCHYLE. Les sept contre Thèbes. In: . Les suppliantes; Les perses; Les sept contre Thèbes; Prométhée enchainé. Quatrième édition revue et corrigée. Texte établi et traduit par Paul Mazon. Paris: Les Belles Lettres, p.110-47, 1946, tome I. (Collection des Universités de France).

EURÍPIDES. As fenícias. In: Ifigênia em Áulis; As fenícias; As bacantes. Tradução do grego, introdução e notas Mário da Gama Kury. Rio de Janeiro: Jorge Zahar, p.109-206, 1993.

FERRAZ JUNIOR. Tercio Sampaio. Introdução ao estudo do direito: técnica, decisão, dominação. São Paulo: Atlas, 1990.

GOMPERZ, Theodor at alii. Greek thinkers: a history of ancient philosophy. London: John Murray, 1949, 4 v.

GUTHRIE, W.K.C. Os filósofos gregos de Tales a Aristóteles. Trad. Maria José Vaz Pinto. Lisboa: Editorial Presença, 1987.

. The 'nomos'- 'physis' antithesis in morals and politics. In:

The sophists. London: Cambridge University Press, p.55-134, 1971.

HESÍODO. Os trabalhos e os dias. (Primeira Parte). 3 ed. Tradução, introdução e comentários Mary de Camargo Neves Lafer. São Paulo: Iluminuras, 1996. (Biblioteca Pólen).

HOBBES, Thomas. Leviatã ou matéria, forma e poder de um estado eclesiástico e civil. 3 ed. Trad. João Paulo Monteiro; Maria Beatriz Nizza da Silva. São Paulo: Abril Cultural, 1983. (Os Pensadores).

I sofisti: fragmenti e testimonianze. Trad. prefazione e note di Maria Timpanaro Cardini. Bari: Gius. Laterza \& Figli, 1923.

JAEGER, Werner Wilhelm. Paidéia: a formação do homem grego. 2 ed. Trad. Artur M. Parreira; adaptação do texto para edição brasileira Mônica Stahel M. da Silva; revisão do texto grego Gilson César Cardoso de Souza. São Paulo - [Brasília]: Martins Fontes - Editora Universidade de Brasília, 1989. 
KERFERD, George Briscoe. The sophistic movement. Cambridge-New York - Melbourne: Cambridge University Press, 1984.

KIRK, G.S.; RAVEN, J.E.; SCHOFIELD, M. Os filósofos pré-socráticos: história crítica com selecção de textos. 4 ed. Trad. Carlos Alberto Louro Fonseca. Lisboa: Fundação Calouste Gulbenkian, 1994.

LAÊRTIOS, Diôgenes. Vidas e doutrinas dos filósofos ilustres. 2 ed. Tradução do grego, introdução e notas Mário da Gama Kury. Brasília: Editora Universidade de Brasília, 1977.

MacINTYRE, Alasdair. Justiça de quem? Qual racionalidade? Trad. Marcelo Pimenta Marques. São Paulo: Edições Loyola, 1991. (Coleção Filosofia-17).

MONDOLFO, Rodolfo. - O homem na cultura antiga: a compreensão do sujeito humano na cultura antiga. Trad. Luiz Aparecido Caruso. São Paulo: Mestre Jou, 1968.

. O pensamento antigo: história da filosofia greco-romana. 3 ed. Trad. Lycurgo Gomes da Motta. São Paulo: Mestre Jou - Editora Universidade de São Paulo, 1971, v.I.

NEWTON CARLOS. Kurtz e Kissinger. Jornal do Brasil. Rio de Janeiro: ${ }^{\circ}$ 205/ano CVIII: p.11, 14-12-1998.

OSTWALD, Martin. Ancient Greek Ideas of Law. In: Dictionary of the history of ideas. New York, Scribner's Sons: p.673-85, 1973, 5v.

. Nomos and the beginnings of the Athenian democracy. Oxford:

Clarendon Press, 1969.

PLATÃO. - A República. 8 ed. Tradução, introdução e notas Maria Helena da Rocha Pereira. Lisboa: Fundação Calouste Gulbenkian, 1996.

. Fedro. In: Diálogos: Mênon - Banquete - Fedro. 4 ed. Trad. Dr. Jorge Paleikat. Rio de Janeiro - Pôrto Alegre - São Paulo: Globo, p.194-263, 1960. (Biblioteca dos Séculos). 
. Górgias ou A Oratória. 3 ed. Tradução, apresentação e notas Jaime Bruna. Rio de Janeiro: Bertrand Brasil, 1989.

. Leis: (Sobre a legislação. Gênero político). In: . Diálogos de Platão: Leis e Epinomis. Trad. Carlos Alberto Nunes. Belém: Universidade Federal do Pará, 1980, v. XII-XIII. (Coleção Amazônica/ Série Farias Brito).

. Protágoras (Ou: Os Sofistas. Gênero demonstrativo). In:

Diálogos de Platão: Protágoras - Górgias - O banquete - Fedão. Trad. Carlos Alberto Nunes. Belém: Universidade Federal do Pará, p.43-108, 1980, v. III - IV. (Coleção Amazônica/ Série Farias Brito).

. Teeteto (Ou: Sobre o Conhecimento. Gênero comprobatório). In: . Diálogos de Platão: Teeteto - Crátilo. Trad. Carlos Alberto Nunes. Belém: Universidade Federal do Pará, p.17-116, 1977, v. IX. (Coleção Amazônica/ Série Farias Brito).

PLATON. Protagoras. In: . Oeuvres complètes. Deuxième édition revue et corrigée. Texte établi et traduit par Alfred Croiset avec la collaboration de Louis Bodin. Paris: Les Belles Lettres, 1948. (Collection des Universites de France).

REALE, Miguel. Filosofia do direito. 14 ed. atual. São Paulo: Saraiva, 1991.

SCHUHL, Pierre-Maxime. Essai sur la formation de la pensée grecque: introduction historique a une étude de la philosophie platonicienne. $2^{\mathrm{a}}$ ed. rev. Paris: Presses Universitaires de France, 1949. (Bibliothèque de Philosophie Contemporaine).

SOUSA, Eudoro. Fontes da história da filosofia antiga: textos traduzidos do grego por Eudoro de Sousa. In: Revista Brasileira de Filosofia. São Paulo: Instituto Brasileiro de Filosofia, 1954, v. IV, fascículos 1 (Janeiro - Março) e 2 (Abril - Junho). Fasc. 1: p. 96-123. Fasc. 2: p. 290-323.

SOUZA, José Cavalvante de. Para ler os fragmentos dos pré-socráticos. In: Os pré-socráticos: fragmentos, doxografia e comentários. Trad. José Cavalvante de Souza et al. São Paulo: Nova Cultural: p. 35-8, 1996. 
(Os Pensadores).

THUCYDIDES. The Peloponnesian War. The complete Hobbes translation; with notes and new introduction by David Grene. Chicago - London: The University of Chicago Press, 1989.

WINDELBAND,Wilhelm. Alvores do pensamento filosófico grego: período cosmológico. In: MAGALHÃES VILHENA, Vasco de. Panorama do pensamento filosófico. Trad. Liselotte Rodrigues; Hermann Pflüger. Lisboa: Edições Cosmos: p.110-89, 1958, v. II.

. Historia de la filosofía antigua. Trad. J. Rovira Armengol. Buenos Aires: Editorial Nova, 1955. (Coleccion La Vida del Espiritu).

ZELLER, Eduard. Outlines of the history of Greek philosophy. 13 ed. Trad. L. R. Palmer; rev. Dr. Wilhelm Nestle. New York: Dover, 1980. 